\title{
Risk Analysis and Calculation of Insurance Premiums on Coffee Export Activities in North Sumatera Province
}

\author{
Sri Fajar Ayu*, Rainal Sunny, and Rahmanta
}

Study Program of Magister Agribusiness, Faculty of Agriculture, Universitas Sumatera Utara, Indonesia

\begin{abstract}
Coffee export activities in North Sumatera can be carried out using a variety of transaction systems. However, any transaction system has risks that may occur at any time. Risk management must be applied in coffee export activities. One common method used to manage risk is to use insurance services. This study aims to identify the type of transaction system that used by coffee exporters in North Sumatera Province, then analyze the risks that can occur in coffee export activities in this province and analyze the amount of insurance premiums on coffee export activities there. The location of the study was intentionally determined, namely in the North Sumatera Province. The research sample was 30 active exporters registered with the Indonesian Coffee Exporters Association of the North Sumatera Regional Board, determined by census. Primary data collected using a questionnaire and secondary data obtained from documentation. Transaction system identified using descriptive methods, while risk analysis is by calculating the risk score value. As for calculating the amount of insurance premiums carried out using BlackScholes. The results found that there were three transaction systems that were used by research respondents in exporting coffee, namely letters of credit, advance payments and open accounts. Open Account is used by all respondents. While the export risk which is a priority risk in this research is at the risk of production. The average value of insurance premiums obtained using the Black-Scholes method is 7.82 percent of the total coverage.
\end{abstract}

Keywords: coffee exports, insurance premiums, risk, transaction systems

Received 12 May 2020 | Revised 06 June 2020 | Accepted 30 June 2020

\section{Introduction}

One of the international trade activities is the export of coffee carried out by exporters in North Sumatera Province. Apart from being a coffee producer, North Sumatera Province with all its potential has also become a coffee exporting country until now. However, the production of coffee shipped from North Sumatera Province has not been able to meet the huge demand for coffee exports. In 2014 to 2015, the volume of coffee exports sold by exporters in North Sumatera Province amounted to the existing coffee production. The increase in export volume in 2015 was far greater than the increase in production volume, increasing in 2016 the volume

\footnotetext{
*Corresponding author at: Study Program of Magister Agribusiness, Faculty of Agriculture, Universitas Sumatera Utara, Jl. Prof Sofyan No. 3, Kampus USU Medan, Indonesia, 20155

E-mail address: srifajar.ayu@gmail.com
} 
of North Sumatera coffee exports increased dramatically around 7,337 tons. Although the volume of coffee production in North Sumatera Province continues to increase from year to year, but the increase is much smaller than the increase in coffee export volume in North Sumatera Province.

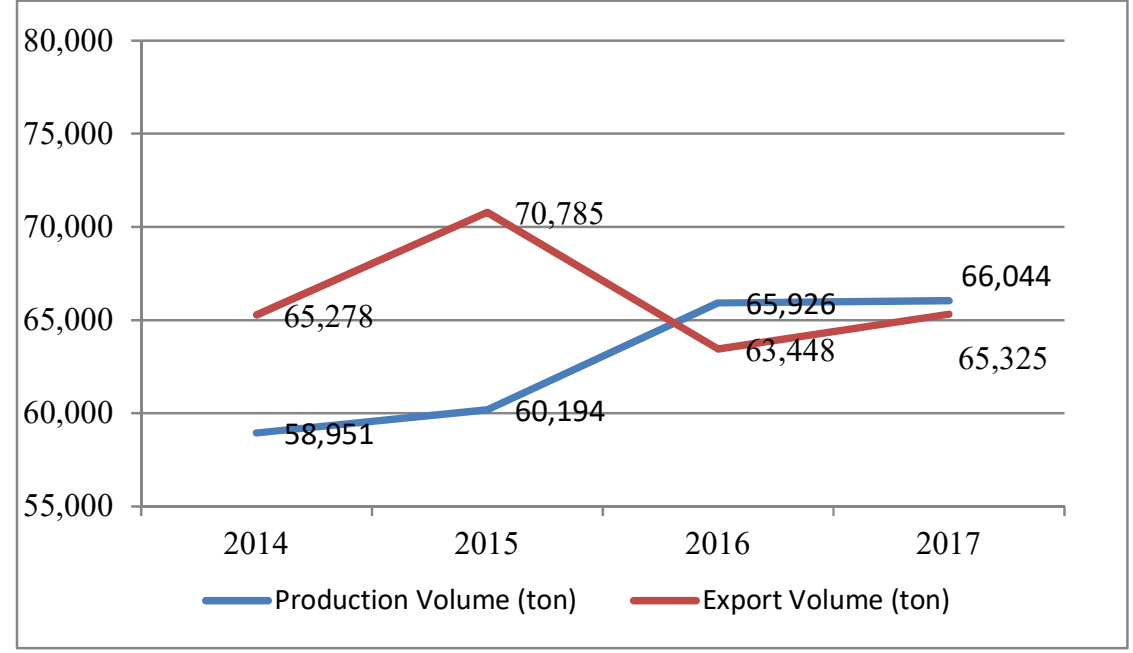

Figure 1. Production and Export Volume of North Sumatera

Figure 1 showed that almost a long 2014-2017, volume of export of coffee from North Sumatera more than its produced. So to fullfil the demand of coffee by importers, the alternative carried out by North Sumatera exporters is to increase the supply of coffee from outside the Province of North Sumatera, which has different tastes and qualities that can pose a risk in coffee export activities carried out by North Sumatera Province exporters. One of the exporters' risks is the risk of breaking promises on non- $\mathrm{L} / \mathrm{C}$ transactions that has the potential to occur, because the guarantee of repayment is the trust between the exporter and importer, not physical [1]. Even so, insurance provides services for exporters using the $\mathrm{L} / \mathrm{C}$ transaction system and non-L/C transactions Existing exporters at the Indonesian Coffee Exporters Association in North Sumatera the increasing level of coffee exports and imports will also face a great risk as well. So Insurance is one of the methods used in dealing with risk, especially if the exporters and importers of coffee do not know each other well. The amount of premium paid by coffee exporters is not the same as general insurance premiums (life, health, coffee farming and so on). In fact, interviews conducted with coffee exporters in Medan showed that no exporters used insurance in export activities. Exporters are still reluctant to use insurance services in export activities. Exporters assume that paying insurance premiums will add to the burden of costs. While on the other hand, the risks faced by exporters are also large, both price risk, broken promises by importers, product rejection, policy and political situation.

From previous studies from Ariasih's research on 2015 which stated that risks are not only faced by exporters, the insurers themselves also face risks that cannot be avoided, let alone inappropriate in managing their insurance funds. So that when a claim occurs before maturity 
and must return it in the form of compensation, insurance is difficult to return the funds. This situation can be anticipated by managing insurance funds properly, including in determining insurance premiums. Therefore, this study will analyze the risk and insurance premium calculation for coffee export activities in the province of North Sumatera and hopefully provide information to resolve the issue [2].

\section{Methods}

\subsection{Location and Sample}

This research was conducted in North Sumatera Province. This location was chosen deliberately with This is North Sumatera which was one of the largest provinces in coffee production in Sumatera Land in 2013-2017 (Table 1) and has an international port which is a gateway for coffee import and export. Sampling which was exported from the Indonesian Coffee Export Association of North Sumatera Province was carried out by census method. Namely by making all the population that became the sample with the population of exporters was 30 exporters, so the number of samples that were respondents of the study were 30 exporters. The data used in this study consisted of primary and secondary data. Primary data collected is data costs incurred to carry out coffee export activities, transaction systems carried out as well as risks that occur in coffee exports. Secondary data consisting of coffee price and volume data is carried out using data collection methods from the Indonesian Coffee Exporter Association of North Sumatera province.

Table 1. Production of Coffee in Sumatera's 2012-2017

\begin{tabular}{clrrrrrr}
\hline No & \multicolumn{1}{c}{ Province } & \multicolumn{1}{c}{$\mathbf{2 0 1 3}$} & \multicolumn{1}{c}{$\mathbf{2 0 1 4}$} & $\mathbf{2 0 1 5}$ & \multicolumn{1}{c}{$\mathbf{2 0 1 6}$} & $\mathbf{2 0 1 7}$ & Average \\
\hline 1 & East Sumatera & 139.754 & 135.287 & 110.352 & 120.904 & 120.792 & 125.418 \\
2 & Lampung & 127.073 & 92.111 & 110.318 & 115.524 & 116.345 & 112.274 \\
3 & North Sumatera & 58.345 & 58.951 & 60.194 & 65.926 & 66.044 & 61.892 \\
4 & Bengkulu & 56.450 & 56.460 & 56.556 & 56.968 & 59.575 & 57.202 \\
5 & Aceh & 48.282 & 49.823 & 47.444 & 65.231 & 68.507 & 55.857 \\
6 & West Sumatera & 32.559 & 33.557 & 34.059 & 22.771 & 21.799 & 28.949 \\
7 & Jambi & 13.326 & 13.583 & 13.447 & 13.395 & 14.034 & 13.557 \\
8 & Riau & 2.601 & 2.465 & 2.843 & 2.782 & 2.913 & 2.721 \\
9 & Bangka Belitung & 3 & 4 & 3 & 3 & 3 & 3 \\
10 & Riau's Islands & 3 & 1 & 0 & 0 & 0 & 1 \\
\hline
\end{tabular}

Source: www.pertanian.go.id, 2018

\subsection{Data Analysis}

Transaction system identification is done using descriptive methods, while risk analysis is done by calculating the risk score value/RSV. Assessment uses numbers 1-10, with number 1 being the lowest risk value, while number 10 indicates the greatest risk. RSV values can be calculated with the following formula [3]: 


$$
\mathrm{RSV}=(\text { Impact Value }) \mathrm{x}(\text { Probability Value })=\mathrm{S} \times \mathrm{O}
$$

RSV value calculated from the expert assessment which filled in the questioner. As for calculating the amount of insurance premiums carried out using Black-Scholes. The following is the formulation of the Black-Scholes method [4] [5] [6]:

$$
\begin{gathered}
C(\mathrm{~S} t, \mathrm{t})=e^{-\left(T^{-} t\right)} \mathrm{E}\left[\operatorname { m a x } \left(S_{\left.T^{-}-K, 0\right)}\right.\right. \\
=e^{-\left(T^{-} t\right)} \mathrm{E}\left[\left(S_{\left.T^{-}-K\right)^{+}}\right.\right. \\
C\left(s_{t}, \mathrm{t}\right)=S_{0} e^{-\left(T^{-} t\right)} \mathrm{N}\left(d_{1}\right)-\mathrm{K} e^{-r\left(T^{-} t\right)} \mathrm{N}\left(d_{2}\right) \\
\mathrm{P}\left(s_{t}, \mathrm{t}\right)=\mathrm{K} e^{-\left(T^{-} t\right)} \mathrm{N}(-d 2)-S_{0} e^{-\delta\left(T^{-} t\right)} \mathrm{N}\left(-d_{1}\right)
\end{gathered}
$$

Where the determination of the values of $\mathrm{d} 1$ and $\mathrm{d} 2$ (derivative values) is as follows:

$$
\begin{aligned}
& d_{l}=\frac{\ln (\boldsymbol{S o} / \boldsymbol{K})+\left(\boldsymbol{r}-\boldsymbol{\delta}+\delta^{2} / 2\right)(T-t)}{\sigma \sqrt{T-t}} \\
& d_{2}=\frac{\ln (S o / K)+\left(r-\delta-\delta^{2} / 2\right)(T-t)}{\sigma \sqrt{T-t}}
\end{aligned}
$$

So based on the above equation, the formula for calculating insurance premiums is obtained, namely [4] [5]:

$$
\text { Premium }=\mathrm{P}=P_{0} e^{-r\left(T^{t}\right)} N\left(-d_{2}\right)
$$

Which is: $\mathrm{C}=$ Coverage $(\mathrm{Rp}) ; \mathrm{St}=$ Stock price $(\mathrm{Rp}) ; \mathrm{r}=$ interest rate $(\%) ; \mathrm{K}=$ Trigger $(\$) ; \mathrm{P}=$ $\operatorname{cost}(\mathrm{Rp})$

\section{Results and Discussion}

\subsection{Transaction System in Coffee Exports in North Sumatera Province}

The majority of research respondents use the Advance Payment (A/P) transaction system in carrying out coffee export activities, especially as of 2019. The A/P transaction system is where the importer has made advance payments to exporters before coffee products are shipped by importers. Generally, respondents who use the A/P transaction system get an advance payment of $40 \%$. The transaction system used by research respondents can be seen in the diagram presented in Figure 2. 


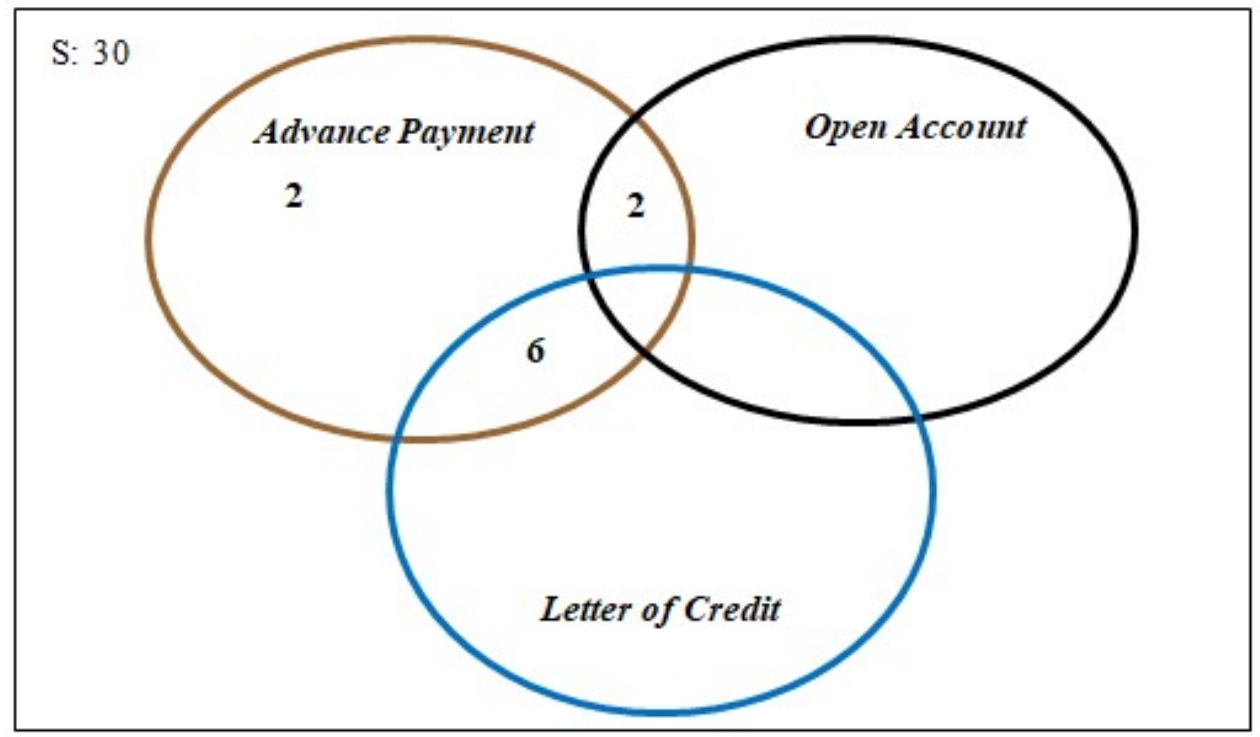

Figure 2. Transaction System Diagram Used by Respondents

Figure 2. shows that there are three types of transaction systems that have been used by respondents in carrying out coffee export activities in North Sumatera Province, namely Advance Payment (A/P), Open Account $(\mathrm{O} / \mathrm{A})$ and Letter of Credit $(\mathrm{L} / \mathrm{C})$. There are 22 respondents (73.33\%) who only use A/P in coffee export activities in North Sumatera Province, but in addition to having used $\mathrm{L} / \mathrm{P}$, respondents also use $\mathrm{A} / \mathrm{P}$, with a total of 6 respondents (20\%). There are $6.67 \%$ of respondents who have also used the Open Account $(\mathrm{O} / \mathrm{A})$ and $\mathrm{A} / \mathrm{P}$ transaction system. Almost the same thing also happened to this respondent, where respondents used the O/A transaction system before 2019. The coffee export activities carried out by respondents since 2019 were with the A/P transaction system. For more details, the A/P transaction system can be seen in Figure 3.

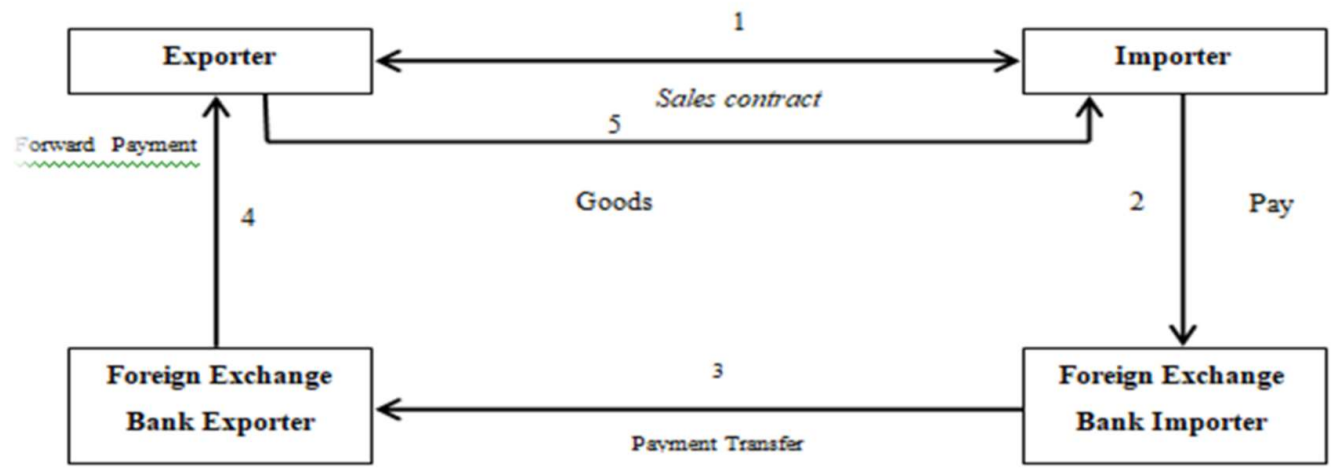

Figure 3. Advance Payment Transaction System (A/P)

As many as $20 \%$ of respondents use the $\mathrm{L} / \mathrm{C}$ and $\mathrm{A} / \mathrm{P}$ transaction system, although on one side the $\mathrm{L} / \mathrm{C}$ transaction system is considered the safest transaction system. However, not all 
exporters use this transaction system on an ongoing basis [7]. The transaction system that has been used by all respondents of this study since 2019 is the A/P transaction system. Some respondents who were on the $\mathrm{A} / \mathrm{P}$ and $\mathrm{O} / \mathrm{A}$ slices or $\mathrm{A} / \mathrm{P}$ and $\mathrm{L} / \mathrm{C}$ since 2019 until the research was conducted, also used A/P. While the transaction system other than A/P is used before 2019 . In the $\mathrm{A} / \mathrm{P}$ transaction system, the importer makes payment in advance a number of agreements that have been agreed at the beginning by the importer and respondent, then repayment to the respondent/exporter after shipping documents and goods have been entered into the section shipping/port. The delivery scheme used by coffee exporters in North Sumatera Province is free on board (FOB). This scheme is a scheme where the exporter is responsible for procuring coffee to the port.

\subsection{Risks in Coffee Export Activities}

To measure the risk of coffee export activities in North Sumatera, this research used the questioner as the instrument. It filled by the expert on coffee export activities which was chosen. From the questioner, the value of risk of coffee export activities in North Sumatera showed in Table 2 . Where the value is higher so does the risk $[3,5,6,8]$.

Table 2. Risk Score Value in Coffee Export Activities of North Sumatera Province

\begin{tabular}{|c|c|c|c|c|c|}
\hline No & Risk Factor & Source Of Risk & $\begin{array}{c}\text { Severity } \\
(S)\end{array}$ & $\begin{array}{l}\text { Occurrence } \\
(\mathrm{O})\end{array}$ & $\begin{array}{l}R S V \\
(S x O)\end{array}$ \\
\hline \multirow{6}{*}{1.} & \multirow{6}{*}{ Production } & Delay in coffee supply & 7 & 6 & 42 \\
\hline & & $\begin{array}{l}\text { Inadequate supply of coffee } \\
\text { from farmers }\end{array}$ & 4 & 7 & 28 \\
\hline & & Coffee quality mismatch & 7 & 4 & 28 \\
\hline & & Coffee damage (defective) & 8 & 5 & 40 \\
\hline & & Storage room is not appropriate & 6 & 4 & 24 \\
\hline & & Pest contaminated & 6 & 4 & 24 \\
\hline \multirow{4}{*}{2.} & \multirow{4}{*}{ Distribution } & Damage to the packaging & 7 & 3 & 21 \\
\hline & & $\begin{array}{l}\text { Accident/theft on the go } \\
\text { (smuggling) }\end{array}$ & 7 & 3 & 21 \\
\hline & & $\begin{array}{l}\text { Export documents are } \\
\text { incomplete }\end{array}$ & 6 & 3 & 18 \\
\hline & & Quality loss & 8 & 4 & 32 \\
\hline \multirow{4}{*}{3.} & \multirow{4}{*}{ Financial } & The value of the dollar is down & 7 & 5 & 35 \\
\hline & & Coffee prices are increasing & 7 & 5 & 35 \\
\hline & & Break the promise/default & 9 & 2 & 18 \\
\hline & & Poor financial statements & 4 & 3 & 12 \\
\hline \multirow{5}{*}{4.} & \multirow{5}{*}{ Policy } & Changes in export regulations & 6 & 2 & 12 \\
\hline & & $\begin{array}{l}\text { Stunted by exports due to } \\
\text { domestic politics }\end{array}$ & 6 & 3 & 18 \\
\hline & & $\begin{array}{l}\text { Misunderstanding of } \\
\text { contracts/transactions (not } \\
\text { carefully looking at contracts) }\end{array}$ & 9 & 3 & 27 \\
\hline & & $\begin{array}{l}\text { Changes in importing country } \\
\text { regulations }\end{array}$ & 7 & 2 & 14 \\
\hline & & $\begin{array}{l}\text { Failed to send due to import } \\
\text { country conflict }\end{array}$ & 8 & 2 & 16 \\
\hline
\end{tabular}


Table 2 shows that the priority risk for coffee export activities in North Sumatera Province lies in production activities, which are due to delays in coffee supply and coffee damage (defects), with RSV values of 42 and 40 respectively. According to respondents, delays in coffee supply from farmers will cause delay in sending export-worthy coffee to the importer, so the product will arrive past the agreed time contracted [8].

\subsection{Costs Covered by Type of Transaction Used by Coffee Exporters in North Sumatera}

The results showed that the average cost borne by respondents in carrying out coffee export activities was Rp.63.443.160/ton. This fee is the cost spent by respondents using their own funding sources and uses a non-L/C payment system. Through a risk study conducted previously, it is recommended to be managed by using insurance services are risks due to broken promises by importers and risks due to conflicts in the importing country, so that coffee fails in delivery [7] [9].

Table 2. Coffee Export Costs by Transaction System

\begin{tabular}{cccc}
\hline No & Transaction System & Assumption & Total Cost (Rp)/Ton \\
\hline \multicolumn{2}{c}{ Average Cost } & & 63.643 .160 \\
1. & Letter of Credit (L/C) & $+25 \%$ & 79.553 .950 \\
2. & Advance Payment (A/P) & $-40 \%$ & 38.185 .896 \\
3. & Open Account (O/A) & - & 63.643 .160 \\
\hline
\end{tabular}

The cost of using the $\mathrm{L} / \mathrm{C}$ transaction system is the highest cost. The difference between average costs and costs borne by exporters using $\mathrm{L} / \mathrm{C}$ is $25 \%$ greater than average costs. While the use of $\mathrm{A} / \mathrm{P}$ transaction system is a transaction system with the costs borne by respondents is the lowest cost. This is because the importer pays upfront assuming $40 \%$ of the total transaction. Meanwhile, the costs borne by respondents if using O/A is Rp.63.643.160/ton.

\subsection{Insurance Premium Calculation on Coffee Export Activities in North Sumatera Province}

The next step is calculated the correlation of Coffee Export Price and Volume in 2014-2018. It is calculated by using the MS. Excel [1] [5]. The higher correlation used for price indexing for the formula.

Table 3. Correlation of Coffee Export Price and Volume in 2014-2018

\begin{tabular}{cccccc}
\hline & Vol 2014 & Vol 2015 & Vol 2016 & Vol 2017 & Vol 2018 \\
\hline P 2014 & 0.17 & 0.06 & -0.34 & -0.45 & 0.54 \\
P 2015 & -0.07 & -0.01 & 0.32 & 0.71 & -0.20 \\
P 2016 & 0.46 & 0.39 & 0.23 & -0.31 & 0.37 \\
P 2017 & -0.27 & -0.14 & -0.33 & 0.12 & -0.12 \\
P 2018 & $\mathbf{0 . 7 5}$ & 0.64 & 0.15 & -0.03 & 0.43 \\
\hline
\end{tabular}


In table 3 this is the result of the correlation between price and volume of North Sumatera coffee exports in 2014-2018 using MS. Excel 2010. The interpretation of the correlation analysis in the table above shows that the strongest relationship value is in the export price of coffee in 2018. So that 2018 was chosen as an index.

Table 4. Price Normality Test Results

\begin{tabular}{cccc}
\hline \multicolumn{4}{c}{ Price Normality Test } \\
\hline Coffee Export Price & $\mathrm{N}$ & Std-Deviation & Asymp. Sig (2-tailed) \\
\hline
\end{tabular}

The results of the normality test resulting from the analysis using SPSS 2.0 are shown in table 4 The amount of data is 12 coffee export price data, then the significance value of 0.200 is obtained. This value is greater than the $5 \%$ confidence level $(0.05)$, so the price data used is normally distributed. Next is determining the amount of coffee export insurance coverage. The insurance price is calculated based on the costs incurred by exporters while carrying out coffee export activities from North Sumatera. From the calculation of primary data obtained in the field, the estimated average coverage price for each ton is obtained, as presented in Table 4 Therefore, the assumption of total coverage is presented in Table 5.

Tabel 5. Coverage Under the Transaction System

\begin{tabular}{cccc}
\hline No & Transaction System & Cost $(\mathbf{R p} /$ ton) & Coverage(Rp) \\
\hline 1. & Letter of Credit $(\mathrm{L} / \mathrm{C})$ & 79.553 .950 & 67.620 .858 \\
2. & Advance Payment $(\mathrm{A} / \mathrm{P})$ & 38.185 .896 & 32.458 .012 \\
3. & Open Account $(\mathrm{O} / \mathrm{A})$ & 63.643 .160 & 54.096 .686 \\
\hline
\end{tabular}

Calculation of Insurance Premiums in the Letter of Credit Transaction System is performed using the Black-Scholes method. In this case, the $S_{0}$ values for the 9 th percentile $=S_{9}$, the 10 th percentile $S_{10}$, the 11 th percentile $S_{11}$, the 12 th percentile $S_{12}$, the 13th percentile $S_{13}$, the 14 th percentile $S_{14}$, and the 15 th percentile $S_{15}$. This percentile calculation is obtained from the coffee export price index in 2018. The following is an illustration of the calculation of coffee export insurance premiums using the Black-Scholes method $[1,2,5,10]$ :

$$
\begin{aligned}
& \mathrm{P}_{0}=P e^{-r\left(T^{2} t\right)} N\left(-d_{2}\right) \\
& d_{2}=\frac{\ln (S o / K)+\left(r-\delta-\delta^{2} / 2\right)(T-t)}{\sigma \sqrt{T-t}}=d_{2}=\frac{\ln (4,835 / 5,5825)+\left(0,065-0-0,4784^{2} / 2\right)(0,08)}{0,4784 \sqrt{0,08}} \\
& d_{2}=-1,052
\end{aligned}
$$

so the value of $\mathrm{N}\left(-\mathrm{d}_{2}\right)=0.137857$. The time period per year can be written as $\mathrm{T}-\mathrm{t}=0.08$ with the standard deviation obtained is 0.4784 . This standard deviation is obtained from calculations using MS. Excel 2010. Variable $\mathrm{K}$ becomes the basis which is defined as the average coffee 
export price of the selected index price. When $S_{9}$ is the 9 th percentile out of 12 available data, the $\mathrm{S}_{9}$ value is $\$ 4.83$. By using the risk free interest assumption of $6.5 \%$. To calculate the premium price, the value of $\mathrm{N}\left(-\mathrm{d}_{2}\right)$ is entered into the formula. Based on the calculation of the 9th percentile cumulative distribution function which is 0.137857 , the premium calculation in this study when the benchmark price is the 9th percentile is:

$$
\begin{aligned}
& \mathrm{P}_{0}=P e^{-r\left(T^{t}\right)} N\left(-d_{2}\right) \\
& =\text { Rp. } 67.620 .858 \times e^{(-0,065 x 0,08)} \times 0,137857 \\
& =\text { Rp.4.733.460 }
\end{aligned}
$$

The coffee export insurance premium paid at 9th percentile is Rp.4.733.460. This study calculates the price of insurance premiums for coffee exports using a price index. As for the premium prices on the Letter of Credit $(\mathrm{L} / \mathrm{C})$ which are selected with other percentile values are presented in Table 6 .

Tabel 6. Premiums for Different Triggers on $\mathrm{L} / \mathrm{C}$

\begin{tabular}{ccccc}
\hline Percentil To & Trigger $\mathbf{( \$ )}$ & Coverage $(\mathbf{R p )}$ & Premium (Rp) & Percentage (\%) \\
\hline 9 & 4.83 & $67,720,858$ & $4,733,460$ & 7.0 \\
10 & 4.86 & $67,720,858$ & $5,003,943$ & 7.4 \\
11 & 4.87 & $67,720,858$ & $5,206,806$ & 7.7 \\
12 & 4.88 & $67,720,858$ & $5,342,048$ & 7.9 \\
13 & 4.90 & $67,720,858$ & $5,477,289$ & 8.1 \\
14 & 4.91 & $67,720,858$ & $5,477,289$ & 8.1 \\
15 & 4.92 & $67,720,858$ & $5,815,394$ & 8.6 \\
\hline
\end{tabular}

The Advance Payment (A/P) transaction system is the transaction system most frequently used by respondents. Costs incurred by respondents using this transaction system are smaller than the $\mathrm{L} / \mathrm{C}$ transaction system, which is Rp.32.458.012. The calculation of the value of insurance premiums obtained is presented in Table 7.

Table 7. Premiums for Different Triggers on A/P

\begin{tabular}{ccccc}
\hline Percentil To & Trigger $(\$)$ & Coverage $(\mathbf{R p})$ & Premium $(\mathbf{R p )}$ & Percentage (\%) \\
\hline 9 & 4.83 & $32,458,012$ & $2,272,061$ & 7.0 \\
10 & 4.86 & $32,458,012$ & $2,401,893$ & 7.4 \\
11 & 4.87 & $32,458,012$ & $2,499,267$ & 7.7 \\
12 & 4.88 & $32,458,012$ & $2,564,183$ & 7.9 \\
13 & 4.90 & $32,458,012$ & $2,629,099$ & 8.1 \\
14 & 4.91 & $32,458,012$ & $2,629,099$ & 8.1 \\
15 & 4.92 & $32,458,012$ & $2,791,389$ & 8.6 \\
\hline
\end{tabular}

Open Account $(\mathrm{O} / \mathrm{A})$ transaction system is a transaction system with the fewest users in this study, which is $6.67 \%$ of the total respondents. In practice, this transaction system has not been used by respondents more than the last 3 years. However, the use of this transaction system is 
when respondents are still joining the old company. The results of the calculation of insurance premiums on the $\mathrm{O} / \mathrm{A}$ transaction system are presented in Table 8 .

Tabel 8. Premiums for Different Triggers for O/A

\begin{tabular}{ccccc}
\hline Percentil To & Trigger $(\$)$ & Coverage $(\mathbf{R p )}$ & Premium $(\mathbf{R p )}$ & Percentage (\%) \\
\hline 9 & 4.83 & $54,096,686$ & $3,786,768$ & 7.0 \\
10 & 4.86 & $54,096,686$ & $4,003,155$ & 7.4 \\
11 & 4.87 & $54,096,686$ & $4,165,445$ & 7.7 \\
12 & 4.88 & $54,096,686$ & $4,273,638$ & 7.9 \\
13 & 4.90 & $54,096,686$ & $4,381,832$ & 8.1 \\
14 & 4.91 & $54,096,686$ & $4,381,832$ & 8.1 \\
15 & 4.92 & $54,096,686$ & $4,652,315$ & 8.6 \\
\hline
\end{tabular}

Table 8 shows the premiums to be paid. The premium is calculated using the Black-Scholes method. The index used in the calculation of premiums in this study is the export price of North Sumatera Province coffee. So the price of coffee has an influence on increasing premium payments, meanwhile the price determined by any factors $[11,12]$. If seen from the value of the percentage of premiums, the average insurance premium obtained is $7.82 \%$. That is, the value of insurance premiums incurred by respondents to use insurance services is $7.82 \%$ of the total costs borne by respondents. So that, by only pay about $7.82 \%$ of the invoice, actually the exporter had guaranteed from the risk or zero risk [1] [5] [9] [10]. So, the insurance of coffee export is a good strategy to manage the risk for the exporter of coffee in North Sumatera.

\section{Conclusion and Recommendation}

\subsection{Conclusion}

The transaction system used by respondents is the Advance Payment (A/P) transaction system, Letters of Credit $(\mathrm{L} / \mathrm{C})$, and Open Account $(\mathrm{O} / \mathrm{A})$. But the transaction system used by all respondents is A/P. Risks that can occur in coffee export activities in North Sumatera Province consist of procurement/coffee production risks, distribution risks, financial risks and policy risks. The highest RSV value is at the risk of production which comes from delays in coffee supply and damage to coffee beans (defects). The value with the highest severity is the risk due to broken promises by importers and importing country conflicts. The value of coffee export insurance premiums obtained varies according to the trigger, the higher the trigger, the greater the premium value obtained. The average insurance premium obtained is $7.82 \%$ of the total coverage. Surely, the premium that ordered by the insurance lower than it, because there are still some considerations like country risk, its class, the product, transportation that used and the transactions method. 


\subsection{Recommendation}

The Letter of Credit (L/C) transaction system is recommended for coffee exporters, especially in establishing trade relations with new coffee importers. This is because risks always have the possibility to occur. Production risk should be a priority risk that must be considered by exporters, so that the supply of coffee with export quality can be obtained properly. Mitigation actions must also be initiated first from production activities and contract making by coffee exporters. It is recommended that risks resulting from broken promises by importers and due to conflicting importing countries are managed using insurance. So that the risks faced can be managed appropriately. Paying a premium to protect export businesses is recommended rather than bearing the losses incurred by the risk.

\section{Acknowledgments}

We would like to thank the DRPM Ministry of Research, Technology and Higher Education (KEMENRISTEKDIKTI) as an institution that has been funding in this research through the 2019 Masters Thesis Research scheme with contracts No. 51/UN5.2.3.1/PPM/KP-DRPM/2019. In addition to the Research Institute (Lembaga Penelitian) of Universitas Sumatera Utara, which has contributed morally and materially.

\section{REFERENCES}

[1] A. A. D. M. Anggraeni, K. Dharmawan, and D. P. E. Nilakusmawati, "Penentuan nilai premi asuransi pertanian berbasis indeks suhu permukaan menggunakan metode burn analysis," E. Jurnal Matematika, vol. 7, no. 4, pp. 322-329, 2018.

[2] M. P. Ariasih, I N. Widana, K. Jayanegara, and I P. E. N. Kencana, "Penentuan cadangan premi untuk asuransi pendidikan," E-Jurnal Matematika, vol. 4, no. 1, pp. 14-19, 2015.

[3] N. Sari and P. Pardian, "Risk analysis of specialty coffee java preanger," Agrisep, vol. 17, no. 1, pp. 79-94, 2018.

[4] S. A. Pramuditya, "Perbandingan metode binomial dan metode black-scholes dalam penentuan harga opsi,“ Jurnal Sainsmat, vol. V, no. 1, pp. 1-6, 2016.

[5] I W. Suarjana, I W. Widia, and K. Dharmawan, "Penentuan nilai kontrak asuransi usaha tani tanaman kopi arabika berbasis indeks harga internasional," Jurnal Beta (Biosistem dan Teknik Pertanian, vol. 5, no. 2, pp. 1-8, 2017.

[6] D. P. Anggraini, D. C. Lesmana, and B. Setiawaty, "Aplikasi simulasi monte carlo untuk menentukan nilai opsi asia dengan menggunakan metode control variate pada komoditas pertanian.," Journal of Mathematics and Its Applications, vol. 16, no. 1, 2017.

[7] A. Andani, Salmiah, and S. F. Ayu, "Faktor-faktor yang mempengaruhi keputusan eksportir kopi menggunakan transaksi non letter of credit pada ekspor kopi Sumatera Utara," Journal of Agriculture and Agribusiness Socioeconomics, Juli 2015.

[8] Sarjiyanto and H. T. Septian, "Mitigasi risiko dalam klaim asuransi pengiriman barang ekspor pada perusahaan internasional freight forwarder (Studi kasus pada PT. MSA Kargo Surakarta," Jurnal Vokasi Indonesia, vol. 7, no. 1, 2019.

[9] R. Hutabarat. Transaksi Ekspor Impor, Edisi Kedua. Jakarta: Penerbit Erlangga, 1994. 
[10] Insyafiah and I. Wardhani, Kajian Persiapan Implementasi Asuransi Pertanian Secara Nasional, Kementerian Keuangan, Badan Kebijakan Fiskal Pusat Pengelolaan Risiko Fiskal, 2014.

[11] T. T. K. Hong, "Effects of exchange rate and world prices on export price of vietnamese coffee," International Journal of Economics and Fianancial Issues, vol. 6, issue 4, pp. 1756-1759, 2016.

[12] C. Lubega and A. Owino, "Analysis of determinants of coffee farm gate prices in Uganda," International Journal of Sciences: Basic and Applied Research, vol. 29, no. 1, pp. 2022011, 2016. 